\title{
Respon Kebijakan Covid-19: Menggairahkan Kembali Ekonomi Indonesia dengan MembukaTravel Bubble dan Koridor Intra- Indonesia
}

\section{Dewa Gde Sugihamretha $^{1}$}

\section{Afiliasi}

${ }^{1}$ Perencana Ahli Utama di Kedeputian Bidang Ekonomi Kementerian Perencanaan Pembangunan Nasional/Bappenas Republik Indonesia

Korespondensi: gde@bappenas.go.id

\begin{abstract}
Abstrak
Istilah travel bubble semakin populer dalam membangkitkan kembali ekonomi dunia melalui kerjasama sektor pariwisata yang terpuruk sejak pandemi Covid-19 melanda. Beberapa negara sedang menjajaki travel bubble dengan perkiraan pelaksanaannya yang perlu mempertimbangkan faktor sosial, ekonomi dan politik. Pro dan kontra terjadi antara pemerintah dengan para ahli sehingga mengulur waktu pelaksanaannya. Indonesia berencana menerapkan travel bubble dengan China, Korea Selatan, Jepang dan Australia, namun menghadapi tantangan karena dalam beberapa minggu terakhir jumlah kasus Covid-19 di Indonesia meningkat tajam. Makalah ini merekomendasikan sejumlah kebijakan. Pertama, agar fokus pada perjalanan wisatawan domestik, karena potensinya yang besar (303,4 juta wisatawan dengan pengeluaran Rp. 291,02 triliun pada tahun 2018). Kedua, membuka kerjasama travel bubble dengan beberapa negara terdekat, menyilakan mereka memilih di antara 13 propinsi di Indonesia yang telah mampu mengendalikan pandemi Covid-19. Saran kebijakan tersebut perlu dilaksanakan dengan pendekatan yang hati-hati dilengkapi persyaratan yang ketat (Indonesia's Prudent Approach), yang kebijakan turunannya juga disampaikan dalam makalah ini.
\end{abstract}

Kata kunci: travel bubble, Covid-19, pariwisata Indonesia, wisatawan domestik, koridor intra-Indonesia.

Doi: https://doi.org/10.47266/bwp.v3i2.73 | halaman: 126-142

Dikirim pada: 07 Juli 2020. Diterima pada: 8 Austus 2020. Dipublikasikan pada: 07 September 2020 


\section{Latar Belakang}

Pandemi Covid-19 telah mempengaruhi perekonomian di seluruh dunia. Sebelum pandemi Covid-19, pariwisata menjadi penggerak sosial dan ekonomi dunia serta telah memberikan sumbangan yang sangat besar pada PDB negara dimanapun. Sejak pandemi Covid-19 sampai hari ini porsi konstribusi kue pariwisata telah hilang sangat signifikan. Dengan demikian, pemerintah di seluruh dunia tak terkecuali Indonesia sedang berjuang untuk menemukan cara-cara cerdik untuk memulihkan perekonomiannya. Salah satu cara yang ditempuh dan tengah menjadi perbincangan hangat disebut dengan travel bubble. Travel bubble merupakan sebuah konsep yang mengemuka sebagai respon terhadap pembatasan perjalanan internasional di tengah pandemi. Pada prakteknya, travel bubble akan memungkinkan perjalanan terbatas antara negara yang menyepakatinya. Hal ini dilakukan dalam rangka mempercepat pemulihan ekonomi bagi negara yang terdampak pandemi. Dengan travel bubble, pengunjung dari negaranegara tersebut dapat melakukan perjalanan dengan lebih mudah, misalnya dengan tidak diwajibkan untuk melakukan karantina mandiri setibanya di negara tujuan.

Travel bubble menjadi kata kunci baru dan kian diminati oleh beberapa negara untuk memulai kembali perjalanan lintas negara di tengah pandemi virus corona (Covid-19). Jauh sebelum terminologi travel bubble dikenal juga istilah tourist bubble. Istilah ini muncul tahun 1950 ketika wisatawan barat melakukan perjalanan karena satu alasan yaitu melarikan diri sebentar dari kenyataan sosial dan kondisi kehidupan kota-kota industri. Namun, upaya untuk melarikan diri seperti itu sia-sia, karena pariwisata sendiri telah menjadi produk komoditi industri. Ini dampak dari liberalisasi industri pariwisata (Enzensberger, 1958). Sebagai hasil komoditi perjalanan, turis massal barat sering dikatakan sebagai wisatawan yang tetap berada dalam batas imajiner tourist bubble dari budaya asli mereka sendiri (Carrier dan Macleod, 2005; Cohen, 1972; Jacobsen, 2003). Para wisatawan tidak mendapatkan hasil yang sesuai dengan harapan yaitu menikmati hal-hal yang asli, eksotis, dan alami, perjumpaan dengan penduduk lokal, budaya, dan bentang alam yang tak tersentuh.

Selain Estonia, Latvia, dan Lithuania ada juga Australia dan Selandia Baru yang berencana melakukan travel bubble. Fiji berharap dapat bergabung dalam travel bubble dengan Australia dan Selandia Baru. Bahkan, Indonesia pun berencana membuka travel bubble dengan empat negara yaitu China, Korea Selatan, Jepang, dan Australia. Negara-negara ASEAN yang telah berhasil meratakan kurve dari Covid-19 menjadi kandidat potensial sedang menjajagi untuk meluncurkan travel bubble seperti Vietnam, Thailand, Singapura, dan Malaysia.

Negara lain merencakanan travel bubble seperti: Jepang dengan Korea, Vietnam, Thailand, Australia, New Zealand; China, Taiwan, Hong Kong, dan Korea Selatan; Israel, Yunani, dan Siprus; serta Inggris dan Perancis.

Makalah ini mencoba memetakan dan menganalisis fenomena pemimpin dunia mencari jalan keluar krisis ekonomi dan sosial yang mereka hadapi dengan cara menghidupkan mesin ekonomi melalui travel bubble, dan membuka Koridor Intra-Indonesia. Makalah ini juga berupaya menyumbangkan gagasan mengenai travel bubble khususnya untuk Indonesia dengan melakukan pembelajaran dari negara-negara seperti kerjasama Estonia, Latvia dan Lithuania; Australia dengan New Zealand,

Tulisan ini bersumber dari berbagai literatur dan desk study, diawali dengan analisis dan pembahasan termasuk didalamnya uraian singkat tentang travel bubble, kebijakan travel 
bubble di beberapa negara, permasalahan pelaksanaan, dilanjutkan dengan analisis situasi pandemi Covid-19 di Indonesia, rencana kebijakan travel bubble Indonesia, dan rekomendasi kebijakan.

\section{Analisis dan Pembahasan}

Wacana travel bubble tengah menjadi perbincangan hangat, tak terkecuali di Indonesia. Melalui travel bubble diharapkan negara-negara yang telah berhasil menekan pandemi Covid-19 membentuk kemitraan untuk menghidupkan kembali pariwisata dan perdagangan.

Sebelum travel bubble dikemukakan dan disepakati oleh kedua negara, ada beberapa syarat dan kriteria yang harus terpenuhi terlebih dahulu. Idealnya adalah negara-negara tersebut sudah berhasil menangani Covid-19 di negaranya agar para pengunjung tidak lagi harus menjalani karantina ketika tiba di sana. Pemerintah harus sangat berhati-hati dan melakukan beberapa langkah ekstra di negaranya sebelum menerapkan travel bubble.

\section{a. Inisiatif dan kebijakan membentuk Travel Bubble}

Travel bubble adalah kemitraan ekslusif antara Negara-negara yang telah menunjukkan keberhasilan dalam menahan dan memerangi pandemi Covid-19 yang bersepakat untuk menciptakan sebuah koridor perjalanan yang disebut juga dengan istilah "Koridor Corona". Koridor ini akan memudahkan penduduk yang tinggal di dalamnya melakukan perjalanan secara bebas dalam Zona, dan menghindari kewajiban karantina mandiri

Penyebaran (proliferation) istilah travel bubble dipelopori oleh tiga negara Baltic yaitu Estonia, Latvia dan Lithuania, ketika mereka membentuk kemitraan trilateral yang memberikan warga negara dari negara-negara tersebut masuk ke wilayah negara-negara anggota. Tidak hanya terbatas pada pariwisata, travel bubble juga memungkinkan ketiga negara Baltic untuk menghidupkan kembali hubungan perdagangan dan sektor-sektor lainnya.

Banyak negara yang mulai mengikuti inisiatif ini atau paling tidak dengan serius mempertimbangkan kemungkinan membentuk blok dengan negara-negara tetangga mereka. Sebagian besar negara umumnya memandang konsep travel bubble sebagai sesuatu yang mampu memulihkan bisnis di berbagai sektor.

Tabel 1. Negara-negara yang telah dan sedang menjajaki Travel Bubble dan Perkiraan Waktu Pelaksanaanya

\begin{tabular}{llll}
\hline No & \multicolumn{2}{c}{ Travel Bubble } & \multicolumn{2}{c}{ Kebijakan dan rencana waktu pelaksanaan } \\
\hline 1. & Estonia, Latvia dan & Estonia, Latvia dan Lithuania secara bersama-sama \\
& Lithuania. & membangun Baltic Travel Bubbles. Penduduk dari ketiga \\
& & negara bebas melakukan perjalanan dengan persyaratan \\
& melakukan isolasi mandiri selama 14 hari. Rencana \\
& pelaksanaan 15 Mei 2020.
\end{tabular}

2. Australia-New Zealand Meskipun belum ada yang resmi, Australia dan Selandia Baru sedang dalam pembicaraan serius membangun koridor korona yang sangat dibutuhkan sesegera mungkin. Kedua negara telah menetapkan dasar bagi koridor perjalanan TransTasman. Rencana pelaksanaan Awal September 2020. 
3. Austria - Jerman
Austria berencana untuk sepenuhnya membuka kembali perbatasannya dengan Jerman. Koridor perjalanan itu akan memungkinkan perjalanan bisnis dan liburan dilakukan antara negara-negara tersebut. Austria juga berencana memperluas wilayah perjalanannya untuk akhirnya mencakup Swiss, Liechtenstein dan negara-negara Eropa Timur yang bertetangga. Rencana pelaksanaan 15 Juni 2020.
4. Kroasia - Slovenia
Negara-negara Baltik Kroasia dan Slovenia membentuk perjanjian untuk membuat gelembung perjalanan bebas karantina. Sektor pariwisata Kroasia menyumbang sekitar 20 persen dari total PDB. Rencana pelaksanaan Mei 2020
5. China - Korea Selatan
Ketika Australia dan Selandia Baru melanjutkan pembicaraan mereka, Cina dan Korea Selatan telah menerapkan travel bubble sejak Mei 2020. Koridor perjalanan yang dikontrol ketat hanya berlaku untuk kota-kota tertentu di kedua negara yang mencakup Seoul ke Shanghai. Koridor perjalanan Tiongkok tampaknya meluas karena ada rencana mengintegrasikan Taiwan, Hong Kong dan bahkan Makau ke dalam zona aman. Rencana pelaksanaan Mei 2020.

\section{Cina - Singapura}

Kedua negara Asia sedang dalam pembicaraan untuk membuat koridor perjalanan mereka sendiri untuk para pebisnis dan pejabat. Diskusi awal tampaknya mengungkapkan prosedur yang masih rumit seperti: hasil tes swab sebelum keberangkatan, rencana perjalanan yang telah disetujui sebelumnya dan Pass SafeTravel, serta penggunaan aplikasi pelacakan kontak negara tuan rumah. Jumlah penumpang yang terbatas dari Singapura dan 6 kota Cina - Shanghai, Tianjin, Chongqing, Guangdong, Jiangsu, dan Zhejiang akan dapat melakukan perjalanan antara kedua negara tanpa menghabiskan masa karantina.

Kedua negara Skandinavia telah sepakat untuk membangun koridor perjalanan dan membuka kembali pariwisata di antara mereka. Baik Denmark dan Norwegia akan mempertahankan pembatasan untuk Swedia, karena Swedia masih merupakan negara dengan kematian terkait virus corona tertinggi di wilayah tersebut.

\footnotetext{
8. Indonesia - Cina, Korea Dalam upaya untuk memulai sektor bisnis dan pariwisata, Selatan, Jepang, Australia Indonesia ingin membentuk koridor perjalanan dengan empat
} 
mitra utamanya. Diprioritaskan dalam koridor perjalanan mendatang adalah para pebisnis. Pembatasan secara bertahap akan dilonggarkan untuk memungkinkan wisatawan datang dan pergi antar negara.

\begin{tabular}{|c|c|c|}
\hline 9. & $\begin{array}{l}\text { EU - Balkan dan Negara- } \\
\text { Negara Eropa Tenggara }\end{array}$ & $\begin{array}{l}\text { Koridor perjalanan antara Uni Eropa, Balkan, dan negara- } \\
\text { negara Eropa Tenggara (Albania, Bosnia dan Herzegovina, } \\
\text { Kosovo, Montenegro, Makedonia Utara, dan Serbia) dibentuk } \\
\text { didasarkan pada pengamatan bahwa situasi epidemiologis di } \\
\text { Balkan dan negara-negara Eropa Tenggara tersebut dianggap } \\
\text { setara atau lebih baik daripada Uni Eropa. Rencana } \\
\text { pelaksanaan } 1 \text { Juli } 2020 \text {. }\end{array}$ \\
\hline
\end{tabular}

10. Inggris - Perancis, Koridor perjalanan yang mencakup Inggris, Prancis, Yunani, Yunani, Italia, Spanyol Italia, dan Spanyol. Meskipun belum ada yang resmi, kami mungkin akan menerima pengumuman resmi tentang koridor yang diusulkan segera. Koridor perjalanan akan memungkinkan warga dari negara-negara tersebut untuk datang dan pergi di antara mereka tanpa harus menjalani karantina. Rencana pelaksanaan 4 Juli 2020.

$\begin{array}{lll}\text { 11. Malaysia - Singapura, } & \text { Pembicaraan tentang "jalur hijau" sedang dilakukan antara } \\ \text { Brunei } & \text { Malaysia, Singapura dan Brunei. Sedang disusun pedoman } \\ & \text { untuk perjalanan lintas batas yang tidak terlalu membatasi } \\ & \text { antara ketiga negara. Kemungkinan kerjasama akan diperluas } \\ & \text { dengan negara-negara yang tidak memiliki kasus infeksi baru } \\ & \text { dalam } 28 \text { hari terakhir seperti Australia dan Selandia Baru. }\end{array}$

12. Thailand - Hong Kong Thailand dan Hong Kong sedang dalam pembicaraan tentang kemungkinan membuka koridor perjalanan di antara mereka setelah Thailand menyambut kunjungan bisnis Hong Kong terpilih yang berasal dari lima yurisdiksi.

Dari tabel diatas menggambarkan bahwa berbagai negara telah melakukan penjajakan kerjasama travel bubble. Setiap negara saling mencermati dinamika perkembangan dalam menghadapi pandemi Covid-19. Tahap awal kerjasama dilakukan oleh negara-negara yang saling berdekatan. Kesepakatan-kesepakatan dituangkan kedalam kebijakan perjanjian kerjasama travel bubble. Negara-negara dikawasan Baltic (Estonia, Latvia dan Lithuania), dan Australia, New Zealand adalah negara yang mengawali kerjasama travel bubble.

Beberapa negara yang memiliki destinasi sangat popular mulai bergerak untuk meningkatkan industri perjalanannya dengan mengundang kehadiran wisatawan. Seperti, Uni Eropa telah mengumumkan akan membuka kembali perbatasan ke 15 negara meliputi 
Aljazair, Australia, Kanada, Georgia, Jepang, Montenegro, Maroko, Selandia Baru, Rwanda, Serbia, Korea Selatan, Thailand, Tunisia dan Uruguay, dan China. Namun, tidak termasuk Amerika Serikat, karena menurut Pusat Sumber Daya Coronavirus Universitas Johns Hopkins, Amerika Serikat dikonfirmasi memiliki jumlah tertinggi infeksi Covid-19 di dunia.

Sementara pulau-pulau di Karibia telah membuka pintu mereka untuk pengunjung asing. Travel bubble juga menjadi lebih populer, setelah orang-orang Fiji, Australia dan Selandia Baru mempertimbangkan untuk mengikuti jejak negara-negara Baltik Estonia, Latvia dan Lithuania yang telah mencabut pembatasan untuk warga negara masing-masing.

\section{b. Dinamika Pelaksanaan Travel Bubble}

Kebijakan travel bubble yang telah disepakati tidak mudah untuk dilaksanakan karena pandemi Covid-19 sangat dinamis. Sewaktu-waktu pandemi yang sudah reda atau menurun mucul kembali. Situasi ini menjadi salah satu faktor penghambat pelaksanaan kebijakan kerjasama travel bubble.

Memperhatikan daily new cases di Australia yang dipublikasikan oleh worldometers tanggal 5 Juli 2020, ditemukan bahwa sejak 15 Februari 2020 sampai dengan 4 Juli 2020 secara umum kasus pandemi Covid-19 di Australia

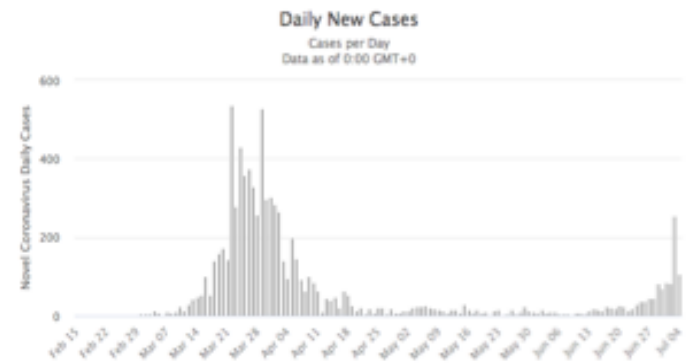

Gambar 1: Daily New Cases In Australia

Sumber: Worldometer

terkelola dengan capaian kemajuan yang sangat baik (Gambar 1.). Daily new cases di New
Zealand pada periode yang sama secara umum kinerja pengelolaan pandemi Covid-19 di New Zealand menunjukkan hasil yang sangat baik.

Pada bulan Mei 2020, dua pemimpin Negara yaitu Australia dan New Zealand yang telah berhasil menangani penyebaran wabah Covid-19 muncul dengan gagasan membuka perbatasan untuk perjalanan bisnis dan pariwisata dengan membentuk Trans-Tasman travel bubble. Dalam memantapkan gagasan ini telah ditandatangani proposal perjanjian yang disebut dengan The trans-Tasman Covid-safe travel zone yang memberikan keleluasaan bagi warga kedua Negara untuk melakukan perjalanan secara bebas. Catatan penting dalam perjanjian ini bahwa warga dari kedua Negara tidak perlu karantina mandiri selama dua minggu.

Adanya travel bubble diharapkan: memudahkan masyarakat melintasi perbatasan dengan kerumitan minimum; peluang bagi berbagai bisnis untuk dibuka kembali sehingga hidup akan kembali seperti biasa. Banyak kalangan menunggu hasil kerjasama Australia dengan Selandia Baru. Keberhasilan kerjasama ini akan menjadi rujukan bagi Negara-negara lain di dunia. Namun, ada juga yang mengingatkan perlu harus berhati-hati untuk tidak melangkah terlalu cepat dan menciptakan gelombang kedua virus corona. Jika terlalu

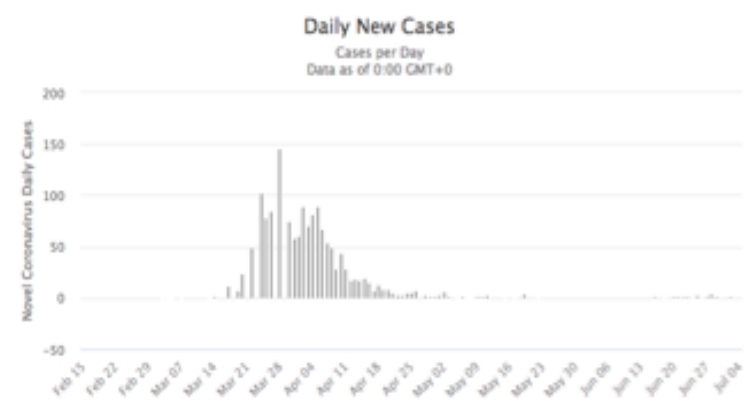

Gambar 2: Daily New Cases in New Zealan cepat, maka hal tersebut akan membahayakan citra kedua negara bagi wisatawan 
internasional yang memandang mereka sebagai negara bersih dan terpercaya.

Pro dan kontra terjadi dalam menetapkan waktu pelaksanaan kebijakan trans-Tasman. Australian Chamber of Commerce mengusulkan penerbangan Canberra ke Wellington pada 1 Juli, tetapi menteri mengatakan terlalu dini untuk menetapkan tanggal. Pemerintah menghadapi tekanan dari kalangan pelaku industri untuk membuka kembali perjalanan trans-Tasman. Bandara Canberra telah membuka daftar minat untuk penerbangan pada 1 dan 2 Juli. Di sisi lain para ahli menyarankan agar trans-Tasman dibuka pada bulan September 2020.

Trans-Tasman menjadi semacam route simbolik ingin menunjukkan bahwa kedua negara telah mengembangkan metode perjalanan udara yang aman dan efektif untuk mendorong perluasan jaringan penerbangan ke tujuan lain di seluruh Australian dan New Zealand. Australia menginginkan percepatan travel bubble mengingat peluang pariwisata untuk Australia adalah menarik 3,1 juta warga New Zealand yang bepergian ke luar negeri untuk datang ke Australia tahun ini. Pre-Covid Australia menerima sekitar 1,3 juta pengunjung dari New Zealand. Namun demikian, pemerintah federal meyakini bahwa perjalanan trans-Tasman masih beberapa bulan lagi mengingat saat ini masih fokus pada pelonggaran penutupan perbatasan domestik yang masih berlaku di Australia. "Saya ingin ini terjadi sesegera mungkin, namun saya belum akan menentukan batas waktunya" (Menteri Pariwisata Federal, Simon Birmingham).

Menurut hasil studi, Trans-Tasman dapat dijalankan dengan aman tanpa perlu karantina. Kuncinya untuk mengurangi resiko adalah penyaringan di kedua penerbangan, tes pasca kedatangan, pemakaian masker, pelacakan kontak. Apapun pendekatannya, yang terpenting adalah manajemen dan evaluasi yang cermat. Penilaian resiko didasarkan pada penapisan penumpang dengan thermal camera dan kuesioner tentang gejala saat kedatangan dan keluar. Penumpang perlu tissue test untuk mengetahui virus tiga hari dan 12 hari setelah kedatangan, mengenakan masker di pesawat dan sampai hasil tes kedua, dan melaporkan sendiri segala gejala. Pelacakan kontak perlu dilakukan.

Menarik opini yang berkembang di Australia bahwa terjadi tsunami amarah (https://www.stuf.co.nz/travel/news)

Tampaknya semakin besar kemungkinan Travel bubble trans-Tasman tidak akan terjadi dalam beberapa bulan mendatang, atau bahkan sampai akhir tahun ini. Berikut adalah enam alasan perjalanan trans-Tasman tampaknya tidak mungkin dilaksanakan dalam waktu dekat:

1. Kemarahan publik. Hal ini terjadi karena masyarakat tidak belajar dari kesalahan, sehingga kondisi negara berada pada level siaga 1. Ditambah dua warga Australia dinyatakan positif setelah berkendara ke Wellington.

2. Kasus Australia. Epidemiolog memperingatkan tentang kemungkinan gelombang kedua yang muncul dari Victoria. Pada tanggal 1 Juli 2020, news.com.au menyampaikan berita bahwa penerbangan komersial pertama TransTasman Bubble ditunda karena ada lonjakan kasus virus di Victoria. Negara Australia sedang berjuang melawan pandemi, dan pembatasan baru diberlakukan. Secara nasional terdapat 25 kasus baru, dengan 463 kasus aktif di seluruh Australia. "Kami hanya bisa berurusan dengan negara-negara Australia Selatan yang tidak memiliki kasus aktif”. Tapi ada masalah besar, Australia Selatan telah melonggarkan pembatasan dengan beberapa negara. Karenanya, tidak mungkin berurusan dengan satu negara saat perbatasannya lemah. Australia tidak 
memiliki strategi eliminasi yang kami lakukan yang bertujuan untuk meminimalkan jumlah orang yang terinfeksi atau sakit dengan Covid-19. Selandia Baru, di sisi lain, memiliki pendekatan zero tolerance. Perbedaan strategi kebijakan antar kedua negara menjadi faktor penghambat sehingga masyarakat Selandia Baru tidak akan memiliki keinginan untuk menyeberang.

3. Pemilihan Umum. Travel bubble TransTasman tidak bisa dibuka sebelum pemilihan umum yang akan dilaksanakan pada 19 September. Jika sebuah kasus Covid-19 muncul yang menyebabkan wabah sebelum pemilihan, maka kemarahan akan diarahkan kepada Pemerintah, resikonya terlalu tinggi.

4. Public mood. Kebanyakan Kiwi (sebutan orange dari New Zealand) tidak menginginkan travel bubble trans-Tasman jika Australia masih mengelola wabah. Tentu, operator pariwisata sangat membutuhkannya. Kiwi tidak menginginkannya sampai aman 100 persen.

5. Intensifikasi virus. New Zealand adalah salah satu dari sedikit negara di dunia yang dapat mengendalikan Covid-19. Tetapi ketika menargetkan 100 persen, tidak ada ruang untuk kesalahan. Virus ini semakin intensif di seluruh dunia, yang berarti lebih banyak kasus akan muncul di perbatasan. Dalam waktu dekat sulit menerapkan perjalanan yang bebas karantina.

6. Dr. Ashley Bloomfield (Director-General of Health and Chief Executive, Ministry of Health Manatū Hauoa. New Zealand Government) mengadopsi pendekatan yang hati-hati. Blommfield bahkan merekomendasikan kepada Pemerintah agar perbatasan ditutup untuk semua orang, termasuk bagi warga Selandia Baru. Tidak ada dalam DNA-nya untuk merekomendasikan melanjutkan perjalanan bebas karantina dengan Australia jika masih memiliki kasus aktif.

\section{c. Update Covid-19 Indonesia}

Uraian berikut ini mencoba menganalisis kesiapan Indonesia dalam rencana kerjasama travel bubble dilihat dari sisi kemajuan dalam menganai pandemi Covid 19. Indonesia sedang bekerja keras mengatasi pandemi Covid-19 walaupun di beberapa daerah sudah mampu diatasi dengan baik, namun di beberapa daerah lainnya masih ada kecenderungan meningkat.

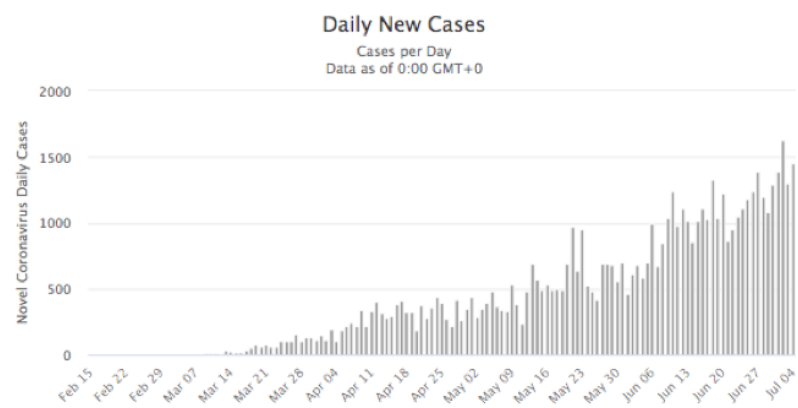

Gambar 3: Daily New Cases in Indonesia

Sumber: Worldometer

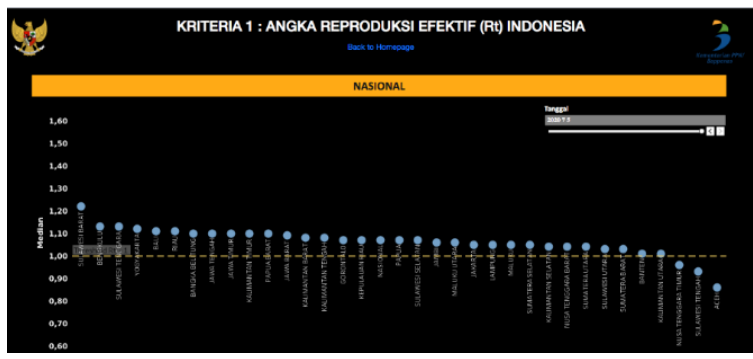

Gambar 4: Angka Reproduksi Efektif (Rt) Indonesia

Sumber: covid.bappenas.go.id

Memperhatikan daily new cases di Indonesia yang dipublikasikan oleh Worldometers tanggal 5 Juli 2020 (Gambar 3), ditemukan bahwa sejak Maret 2020 sampai dengan 4 Juli 2020 secara umum kasus pandemi Covid-19 di Indonesia masih berfluktuasi, grafiknya sedikit meningkat, satu daerah 
Tabel 2. Report Corona Virus Cases: 3 Juli 2020

\begin{tabular}{|c|c|c|c|c|c|c|c|c|c|c|c|c|c|}
\hline$\#$ & $\begin{array}{l}\text { Country, } \\
\text { Other }\end{array}$ & $\begin{array}{l}\text { Total } \\
\text { Cases } \quad \not \mathbb{F}\end{array}$ & $\begin{array}{l}\text { New } \\
\text { Cases }\end{array}$ & $\begin{array}{l}\text { Total } \\
\text { Deaths }\end{array}$ & $\begin{array}{l}\text { New } \\
\text { Deaths }\end{array}$ & $\begin{array}{l}\text { Total } \\
\text { Recovered }\end{array}$ & $\begin{array}{l}\text { Active } \\
\text { Cases }\end{array}$ & $\begin{array}{l}\text { Serious, } \\
\text { Critical }\end{array}$ & $\begin{array}{l}\text { Tot Cases/ } \\
\text { 1M pop }\end{array}$ & $\begin{array}{l}\text { Deaths/ } \\
1 \mathrm{M} \text { pop }\end{array}$ & $\begin{array}{l}\text { Total } \\
\text { Tests }\end{array}$ & $\begin{array}{l}\text { Tests/ } \\
1 \mathrm{M} \text { pop }\end{array}$ & Population \\
\hline 1 & $\begin{array}{l}\text { New } \\
\underline{\text { Zealand }}\end{array}$ & 1,534 & +1 & 22 & & 1,490 & 22 & 1 & 307 & 4 & 415,283 & 83,022 & $5,002,100$ \\
\hline 1 & Australia & 8,586 & +137 & 106 & +2 & 7,420 & 1,060 & 6 & 337 & 4 & $2,751,473$ & 107,888 & $25,503,005$ \\
\hline 1 & Indonesia & 64,958 & $+1,209$ & 3,241 & +70 & 29,919 & 31,798 & & 237 & 12 & 928,238 & 3,393 & $273,555,636$ \\
\hline 1 & Malaysia & 8,668 & +5 & 121 & & 8,476 & 71 & 2 & 268 & 4 & 810,057 & 25,025 & $32,370,116$ \\
\hline 1 & Singapore & 44,983 & +183 & 26 & & 40,441 & 4,516 & 2 & 7,688 & 4 & 757,746 & 129,509 & $5,850,914$ \\
\hline 1 & Phillippines & 46,333 & $+2,079$ & 1,303 & +6 & 12,185 & 32,845 & 166 & 423 & 12 & 798,476 & 7,286 & $109,595,187$ \\
\hline 1 & Thailand & 3,195 & +5 & 58 & & 3,072 & 65 & 1 & 46 & 0.8 & 603,657 & 8,648 & $69,802,624$ \\
\hline 1 & $\underline{\text { Vietnam }}$ & 369 & +14 & & & 341 & 28 & 1 & 4 & & 275,000 & 2,825 & $97,348,975$ \\
\hline 1 & Japan & 19,522 & & 977 & & 17,050 & 1,495 & 33 & 154 & 8 & 495,164 & 3,915 & $126,469,561$ \\
\hline 1 & S. Korea & 13,137 & +46 & 284 & +1 & 11,848 & 1,005 & 15 & 256 & 6 & $1,331,796$ & 25,976 & $51,269,887$ \\
\hline 1 & China & 83,557 & +4 & 4,634 & & 78,518 & 405 & 5 & 58 & 3 & $90,410,000$ & 62,814 & $1,439,323,776$ \\
\hline 1 & India & 704,607 & $+6,771$ & 19,782 & +82 & 429,907 & 254,918 & 8,944 & 511 & 14 & $9,969,662$ & 7,224 & $1,380,159,707$ \\
\hline
\end{tabular}

Sumber: Worldometer

menurun dan daerah lainnya meningkat, belum ada tanda-tanda mereda walaupun angka reproduksi efektif (Rt) nya menunjukkan angka yang baik rata-rata di angka 1 . Tertinggi Rt 1,2 (Sulawesi Barat), dan yang terendah Rt 0,8 di Aceh. (Gambar 4)

Dari sisi tes Covid-19, banyak kalangan mempertanyakan jumlah tes yang masih sangat rendah di Indonesia. Dari data di atas (Tabel 2) nampak bahwa sampai dengan 3 Juli 2020 Indonesia melakukan tes sebanyak 928.238 orang dengan tes/1M pop hanya 3.393 . Jumlahnya sangat kecil sekali dibandingkan dengan negara seperti China, India, Korea Selatan, Singapura, dan Malaysia. Kalau ini terus dipertahankan tanpa ada terobosan besar maka masih akan diperlukan jalan panjang untuk menuntaskan pandemi Covid-19 dan dikhawatirkan korban akan terus berjatuhan.

Memperhatikan data curve kasus Covid19 harian baru vs waktu, dengan rata-rata 14 hari pada Gambar 5, nampak bahwa dari 34 propinsi terdapat 13 propinsi yg telah berhasil keluar dari tanjakan pandemi Covid-19 yang ditandai dengan laju curve semakin menurun menuju datar seperti: Sumatera Barat, Kepulauan Riau, Jambi, Lampung, Bengkulu, Kepulauan Bangka Belitung, DI. Yogyakarta, Nusa Tenggara Timur, Kalimantan Utara, Sulawesi Barat, Sulawesi Tengah, Gorontalo, dan Papua Barat. 13 Propinsi dapat dibuka menjadi pintu kerjasama travel bubble dan Coridor Domestik. 


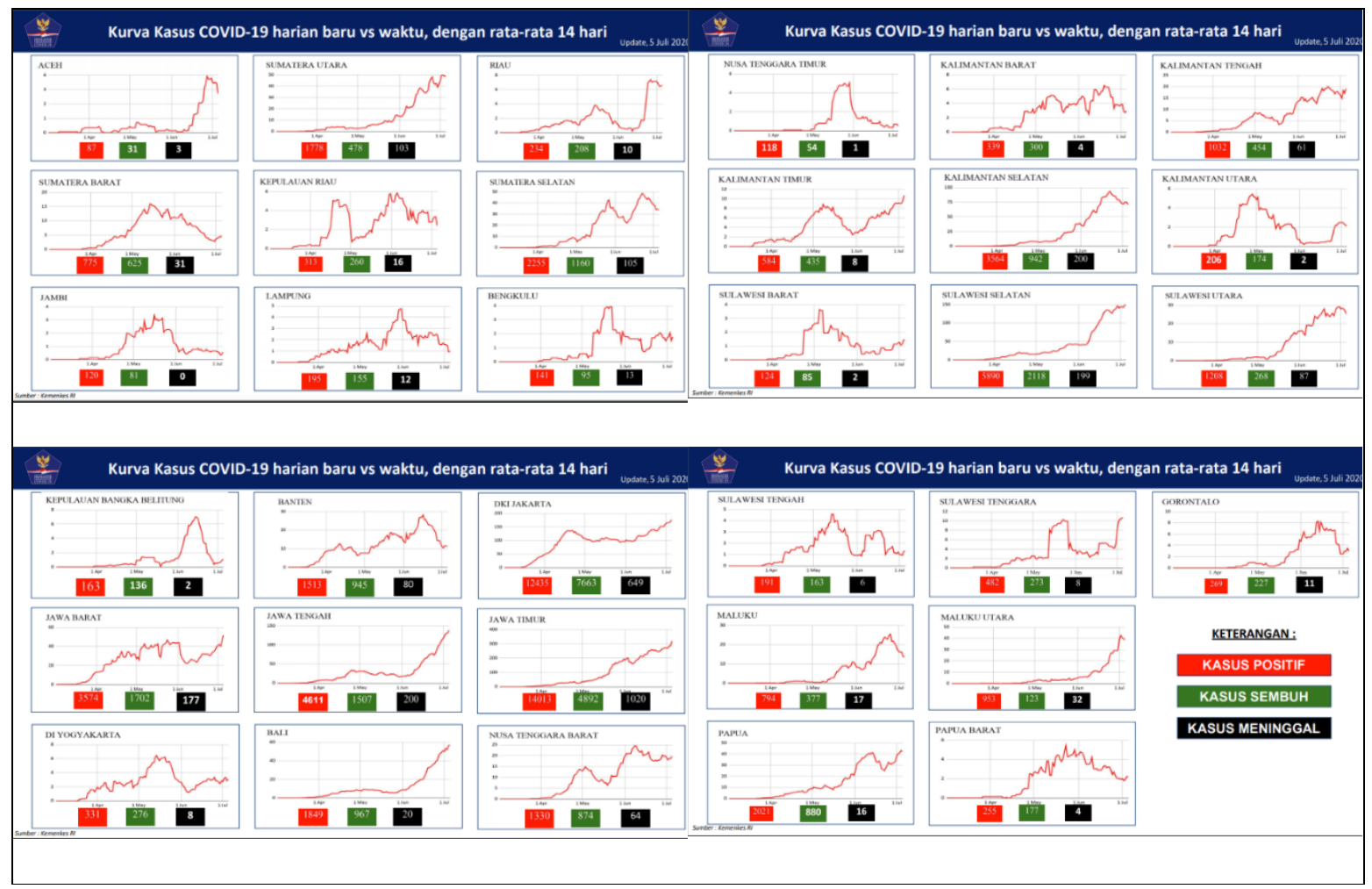

Gambar 5: Kurva Kasus Covid-19 Harian Baru VS Waktu, Dengan Rata-rata 14 Hari

Sumber: covid.bappenas.go.id

\section{d. Rencana Travel Bubble Indonesia}

Dalam rangka menggairahkan kembali perekonomian di dalam negeri, Indonesia berencana membuka perbatasan dengan beberapa negara tetapi menutup untuk negara lain atau kini dikenal sebagai kebijakan travel bubble. Berdasarkan pembahasan dalam rapat kabinet terbatas pada 28 Mei 2020 ada 4 negara yang akan menjadi mitra travel bubble Indonesia yaitu China, Korea Selatan, Jepang dan Australia dengan memperhatikan nilai ekonomi dan faktor kesehatan.

Dari sisi ekonomi, memperhatikan data yang dipublikasikan oleh Badan Koordinasi Penanaman Modal (BKPM) terkait dengan realisasi investasi Triwulan I (periode Januari Maret) Tahun 2020, dengan total investasi mencapai Rp 210,7 triliun, naik 8,0\% dibanding periode yang sama tahun 2019, yaitu sebesar Rp 195,1 triliun. Dibandingkan tahun 2019, pertumbuhan investasi PMDN pada Triwulan I Tahun 2020 meningkat sebesar 29,3\%, dari Rp 87,2 triliun di Triwulan I Tahun 2019 ke Rp 112,7 triliun. Sedangkan, investasi PMA pada Triwulan I Tahun 2020 tersebut melambat 9,2\% dibanding Triwulan I Tahun 2019 yang sebesar Rp 107,9 triliun menjadi Rp. 98,0 triliun.

Lima besar negara asal PMA adalah negara yang termasuk dalam rencana membuka kerjasama travel bubble yaitu: Singapura (US\$ 2,7 miliar, 40,0\%); R.R. Tiongkok (US\$ 1,3 miliar, 18,9\%); Hongkong, RRT (US\$ 0,6 miliar, 9,3\%); Jepang (US\$ 0,6 miliar, 8,9\%) dan Malaysia (US\$ 0,5 miliar, 7,1\%). 
Menariknya, negara-negara yang akan direncanakan bekerjasama dalam travel bubble juga penyumbang terbesar dalam penerimaan devisa dari para wisatawan manca Negara. Berdasarkan data Badan Pusat Statistik (BPS) kunjungan wisman dari China ke Indonesia pada 2019 mencapai 2.072.079. Sementara wisman dari Korea Selatan mencapai 388.316, Jepang mencapai 519.623, dan Australia mencapai 1.386 .803 orang.

Jadi berdasarkan data-data yang ada tidak salah Indonesia memilih kerjasama travel bubble dengan keempat Negara tersebut ditambah dengan beberapa Negara dilingkungan ASEAN sehingga harapannya adalah disamping dapat pelancong dari bisnis juga dari wisatawan.

Namun, Indonesia menghadapi tantangan dalam membuka pintu kerjasama travel bubble, bulan lalu pemerintah Perdana Menteri Shinzo Abe meluncurkan diskusi dengan Australia, Selandia Baru, Thailand, dan Vietnam tentang menciptakan travel bubble di masa depan, dan Jepang sedang memperluas negosiasi ke 10 negara lagi, pembicaraan akan dimulai pertengahan Juli 2020. Pada konferensi pers pada 10 Juli 2020, Menteri Luar Negeri Jepang Toshimitsu Motegi mengatakan bahwa mereka berencana untuk meluncurkan kembali perjalanan secara bertahap, mulai dari negaranegara yang telah menekan penyebaran dan transmisi virus. Empat dari mereka - yaitu Cina, Mongolia, Korea Selatan, dan Taiwan berada di Asia Timur, sementara negara-negara Asia Tenggara yang dipertimbangkan untuk skema tersebut termasuk Brunei, Kamboja, Laos, Malaysia, Myanmar, dan Singapura. Perjanjian timbal balik pada akhirnya akan memungkinkan perjalanan untuk melanjutkan dari semua negara anggota ASEAN kecuali untuk Indonesia dan Filipina. Kedua negara memiliki kasus virus corona yang baru dikonfirmasi yang jumlahnya meningkat tajam dalam beberapa minggu terakhir.

\section{e. Champion Travel Bubble Indonesia}

Kecenderungan membaiknya penanganan pandemi Covid-19 di 13 propinsi sebagaimana nampak pada Gambar 5, bisa menjadi rujukan sebagai propinsi yang siap menjadi calon (champion) koridor travel bubble. Dari 13 propinsi terdapat beberapa propinsi yang selama ini menjadi champion kunjungan wisman yang cukup besar setelah Bali yaitu:

1. Propinsi Kepulauan Riau. Jumlah wisman yang datang ke kepulauan Riau pada tahun 2019 sebanyak 2,8 juta orang. Selain melalui pintu Hang Nadim International Airport-Batam, terdapat pintu masuk utama terbanyak melalui jalur laut menuju beberapa pintu laut seperti: Batam, Tanjung Uban, Tanjung Pinang, dan Tanjung Balai Karimun. Wisman yang berkunjung ke Kepri didominasi oleh wisman dari Singapura disusul Malaysia,Tiongkok, India. Keunggulan Propinsi Kepulauan Riau sebagai koridor travel bubble adalah destinasinya berada dalam enclave sehingga wisman dapat tinggal di pulau-pulau seperti di pulau Bintan dengan Lagoi Beach, Pulau Bawah, Pulau Nikoi island, Pulau Funtasy island dan masih banyak lagi pulau2 lainnya selain Batam yang sudah mendunia.

2. DI Yogyakarta. Pada tahun 2019, DI. Yogyakarta kedatangan 651.000 wisatawan manca Negara dan 24,3 juta wisatawan nusantara. Sultan HB X telah memperpanjang masa tanggap darurat bencana Covid-19 untuk periode kedua hingga 31 Juli 2020 mendatang. Obyek wisata, hotel, restoran sudah mulai buka kembali. Belum semua kabupaten di DI. Yogyakarta memiliki kesiapan melakukan 
pelacakan untuk menemukan wisatawan positif terinfeksi virus corona. Untuk itu, DIY mengembangkan aplikasi pendataan pengunjung dengan metode QR Code, yang telah lebih dulu diterapkan di kawasan Malioboro. Dengan beroperasinya Bandara Internasional Yogyakarta di Kulon Progo per April 2020 diharapkan jumlah wisman yang datang akan tembus lebih dari 1 juta orang. Tantangan DIY sebagai salah satu destinasi sebagai koridor travel bubble adalah posisinya berhimpitan dengan wilayah pandemi Covid-19 Jawa Tengah, dan Jawa Timur. Di samping itu, daratan Jawa yang jumlah penduduknya terpadat di Indonesia juga menyumbang cukup signifikan pandemi Covid-19.

3. Propinsi Sumatera Barat. Jumlah kunjungan wisman ke Sumatera Barat tahun 2019 melalui pintu bandara Internasional Minangkabau sebanyak 61.000 orang didominasi oleh wisatawan dari Malaysia, Australia, Singapura, Perancis, dan Amerika Serikat.

4. Propinsi Papua Barat. Pada tahun 2018, jumlah kunjungan wisatawan ke Papua Barat 364.026 orang terdiri dari wisman 12.790 orang dan wisnus 351.236 orang. Icon utama destinasi Papua Barat adalah Raja Ampat. Kunjungan wisatawan ke Raja Ampat tahun 2018 berjumlah 43.910 orang terdiri dari wisman 23.099 orang dan wisnus 20.811 orang (Raja Ampat Dalam Angka,2018).

5. Propinsi Nusa Tenggara Timur. Jumlah kunjungan wisatawan ke NTT pada tahun 2018 berjumlah 1.239 .432 orang terdiri dari wisman 128.241 orang dan wisnus 1.111 .191 orang. Icon utama destinasi NTT adalah Labuan Bajo menjadi salah satu dari 5 destinasi super prioritas. Di NTT juga terdapat banyak akomodasi yang sudah dikenal dunia, salah satunya adalah Nihiwatu didapuk sebagai hotel terbaik di dunia tahun 2016 oleh majalah wisata Travel+Leisure.

6. Delapan Propinsi lainnya yaitu Jambi, Lampung, Bengkulu, Kepulauan Bangka Belitung, Kalimantan Utara, Sulawesi Barat, Sulawesi Tengah, dan Gorontalo juga memiliki potensi besar di sektor pariwisata.

Pulau Bali merupakan barometer perke mbangan pariwisata nasional yang merupakan daerah tujuan utama pariwisata Indonesia. Sebagai salah satu pusat wisata dengan kedatangan turis yang tinggi, Bali sering kali dikhawatirkan akan menjadi episentrum Covid-19 di Indonesia. Pada bulan Mei 2020, banyak kalangan mengapresiasi sekaligus melayangkan pujian Bali berhasil dalam mengendalikan Covid-19 meski tak menerapkan Pembatasan Sosial Berskala Besar (PSBB). Bahkan ada himbauan agar pemerintah daerah lain untuk meniru Bali. Namun, kini Bali menghadapi persoalan baru, kasus transmisi lokal Covid-19 mengalami peningkatan.

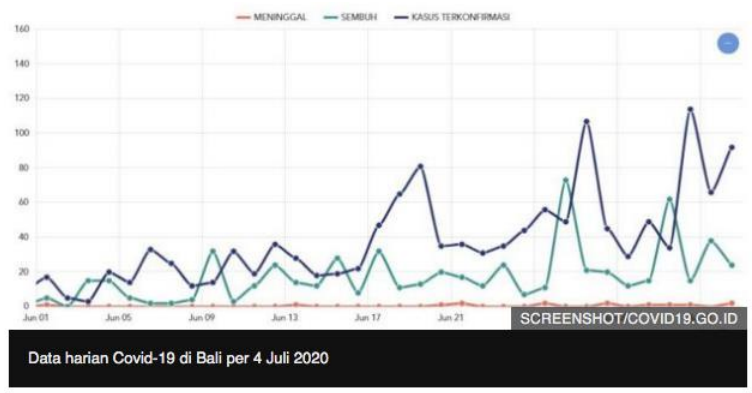

Gambar 6. Data Harian Covid-19 di Bali

Gambar 6 menunjukkan bahwa hingga 4 Juli 2020 terdapat 1.849 kasus positif dengan 20 kematian. Adapun pasien sembuh sebanyak 967 orang sedangkan pasien dalam perawatan mencapai 862 orang (Data Gugus Tugas Percepatan Penanganan Covid-19 Bali) 
Berbagai media di Bali mengabarkan, dalam kondisi pandemi Covid-19 yang masih belum mereda di Bali, Bali berencana menerima kembali wisatawan dalam negeri pada akhir bulan Juli. Sedangkan wisatawan asing akan dibolehkan berkunjung ke Bali mulai September 2020.

Gubernur Bali menyatakan bahwa Bali berhasil mengendalikan penyebaran pandemi Covid-19. Hasil yang baik tersebut ditandai dengan terkendalinya muncul kasus positif baru, tingkat kesembuhan yang tinggi, dan jumlah yang meninggal relatif kecil. Karena sudah berhasil tersebut, maka Bali pun akan memulai penerapan normal baru (new normal) termasuk untuk pariwisata. Penerapan normal baru itu akan dilakukan dalam tiga tahap. Pertama, melaksanakan aktivitas secara terbatas dan selektif hanya untuk lingkup lokal masyarakat Bali dimulai pada Kamis, 9 Juli 2020; tahap kedua, mulai dibuka untuk aktivitas lebih luas, termasuk sektor pariwisata, tetapi hanya terbatas untuk turis domestic dimulai pada 31 Juli 2020; tahap ketiga, melaksanakan aktivitas secara lebih luas sektor pariwisata termasuk untuk turis asing mulai 11 September 2020.

Pakar Epidemiolog memberi peringatan kepada pemerintah Bali agar membuka wisata secara bertahap dengan ketentuan protokol Covid-19. Pemerintah Bali harus memastikan wisatawan yang datang ke Bali bukan berasal dari zona merah. Kemudian, jumlahnya juga harus dibatasi termasuk tempat-tempat wisata yang dibuka. Perlu ada pemantauan secara berkala termasuk pemberian sanksi yang tegas bagi pengelola wisata yang melanggar protokol Covid-19. Ketika itu tidak dipatuhi, harus ada punishment (Universitas Airlangga, Laura Navila Yamani). Guru besar virologi Universitas Udayana menilai penerapan normal baru di Bali termasuk buru-buru. Apalagi jumlah kasus positif Covid-19 di Bali terus meningkat sebagaimana nampak pada Gambar 6.

\section{f. Membuka Koridor Intra-Indonesia}

Banyak kalangan kurang memberikan perhatian pada kekuatan wisatawan domestik. Kedepan, Indonesia dengan kelas memengah yang terus meningkat dan kecenderungan akan melakukan perjalanan wisata. Untuk itu, saya menggunakan istilah koridor Intra-Indonesia adalah koridor perjalanan wisatawan domestik Indonesia dari satu propinsi ke propinsi lainnya yang dapat melakukan perjalanan secara bebas dengan mengikuti protokol kesehatan yang ditetapkan oleh WHO dan ketentuan-ketentuan yang ditetapkan oleh Gugus Tugas Covid-19 Indonesia. Pembukaan koridor ini utamanya untuk propinsi-propinsi yang telah mampu mengelola dengan baik pengendalian pandemi Covid-19. Membuka koridor Intra-Indonesia sangatlah penting guna menggerakkan roda ekonomi Indonesia mengurangi dampak sosial ekonomi seperti pengangguran, kemiskinan yang semakin meningkat.

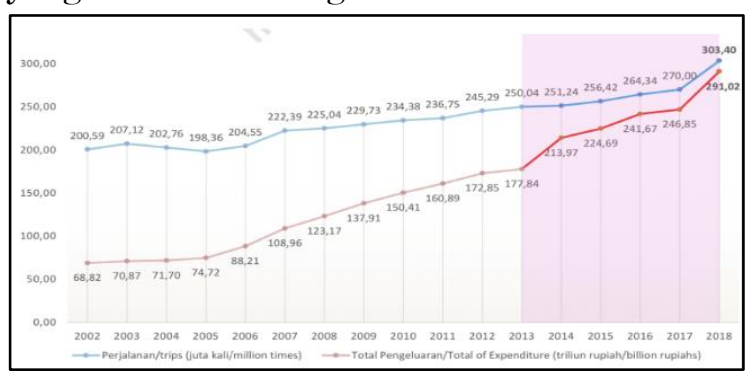

Gambar 7. Trend perjalanan wisatawan domestik

\section{Sumber: LPEM-UI}

Sebagaimana diketahui memperhatikan trend perjalanan wisatawan domestik dari tahun 2002 sampai dengan tahun 2018 walaupun Indonesia menghadapi berbagai permasalahan seperti tragedi 911, Bom Bali, Bom Jakarta Thamrin, dan Krisis ekonomi 2009, wisatawan domestik terus mengalami peningkatan. 
Perjalanan wisatawan domestik pada tahun 2018 sangat tinggi yaitu 303,4 juta jumlah perjalanan dengan total pengeluaran sebesar Rp. 291,02 triliun (Gambar 7).

\section{Kesimpulan dan Rekomendasi}

Gagasan untuk membangun kerjasama membuka pintu perjalanan dari satu negara ke negara lain melalui travel bubble diharapkan dapat menghidupkan kembali mesin ekonomi dunia termasuk di dalam negeri. Namun dari hasil pembelajaran dari beberapa negara yang merencanakan untuk membuka kerjasama melalui travel bubble, dalam pelaksanaannya tidak mudah dieksekusi. Banyak kalangan menunggu hasil kerjasama travel bubble antara Australia dengan New Zealand untuk menjadi model pembelajaran. Namun sampai saat ini kedua negara belum melaksanakan kesepakatan kerjasama tersebut dengan berbagai pertimbangan baik sosial, ekonomi dan politik.

Indonesia sebagai negara besar perlu merencanakan dengan matang strategi untuk menghidupkan kembali mesin ekonomi melalui pariwisata dengan membangun kerjasama travel bubble dan membuka koridor Intra-Indonesia.

Beberapa rekomendasi kebijakan sebagai langkah-langkah tindak lanjut yang diperlukan sebagai berikut:

1. Memperioritaskan membuka koridor Intra-Indonesia sebagai simpul utama berfokus pada wisatawan domestik untuk menghidupkan kembali roda ekonomi Indonesia melalui perjalanan pariwisata ke seluruh Tanah Air. Dengan dorongan stimulus ekonomi dampak pandemi Covid-19, jutaan pergerakan wisatawan domestik yang melibatkan banyak kelas menengah diharapkan mampu menggairahkan kembali perekonomian dalam negeri, mengkonsumsi barang dan jasa yang dihasilkan oleh perusahaanperusahaan Indonesia yang didominasi oleh UMKM sebagai salah satu mata rantai ekonomi pariwisata selain industri dan akomodasi lainnya. Kegiatan-kegiatan MICE pemerintah dan dunia usaha segera digerakkan ke daerah-daerah. Di samping itu, penduduk dapat mengambil liburan selama bulan Agustus sampai September untuk bergerak ke destinasi-destinasi favorit mereka. Hotel-hotel di Indonesia akan bergantung pada pariwisata domestik mengingat wisatawan manca negara memerlukan waktu lama kembali berkunjung ke Indonesia.

2. Paralel dengan tahap butir 1 di atas, membuka kerjasama travel bubble dengan beberapa negara terdekat seperti Australia, Negara-negara ASEAN, Jepang, Korea Selatan, dan China. Propinsi-propinsi yang saat ini layak masuk dalam menu kerjasama travel bubble adalah 13 propinsi yang telah mampu mengendalikan pandemi Covid19. Dipersilakan mitra negara kerjasama yang akan memilih dari ke 13 propinsi yang ada. Adapun propinsi Bali yang saat ini berjuang keras mengendalikan pandemi Covid-19, bisa ditawarkan sebagai menu optional dalam travel bubble dengan pergerakan yang terbatas di kawasan Nusa Dua dan Pulau Nusa Penida, dapat diperluas ke daerah lain kalau telah berhasil mengendalikan dengan baik pandemi Covid-19.

3. Mengingat perubahan peta pandemi Covid-19 sangat dinamis, disarankan agar Gugus Tugas Pandemi Covid-19 bidang pariwisata melakukan pemantauan dan pengendalian secara terus-menerus sehingga data dan informasi dampak Covid-19 bidang 
pariwisata di seluruh propinsi terpantau dengan real time. Hasile perbaikan kinerja propinsi dalam pengendalian pandemic Covid-19 bisa dijadikan dasar menambah menu-menu propinsi yang bisa ditawarkan dalam perluasan kerjasama travel bubble dengan Negaranegara lainnya.

4. Meningkatkan pelaksanaan tes yang saat ini hanya 3.393 tes/1M Pop.

Keberhasilan pelaksanaan rekomendasi tersebut harus dilaksanakan dengan pendekatan yang hati-hati dengan persyaratan yang ketat dalam pembangunan pariwisata Indonesia memasuki penerapan normal baru (new normal), Indonesia's Prudent Approach. Dibawah ini diuraikan beberapa pilihan kebijakan (policy options) sebagai persyaratan yang harus dipenuhi meliputi:

1. Menyusun perjalanan domestik di zona khusus pariwisata aman (special "safe" tourism zones).

2. Hotel dan bisnis diizinkan untuk dibuka kembali asalkan mereka telah menerima sertifikat kesiapan Covid-19. Pengunjung juga akan diminta untuk mematuhi protokol lokal, seperti mengenakan masker wajah, dan menjaga jarak.

3. Pemerintah perlu mempertimbangkan untuk mengeluarkan izin pariwisata aman untuk fasilitas wisata sesuai dengan peraturan perundang-undangan dan persyaratan keselamatan tertentu, seperti memiliki tenaga medis bersertifikat dan memegang stok peralatan APD yang memadai.

4. Otoritas pariwisata baik Pusat maupun Daerah perlu menciptakan cap sertifikasi higiene gratis berlaku satu tahun untuk membedakan perusahaan pariwisata bersih \& aman untuk meningkatkan kepercayaan pengunjung. Bisnis harus mematuhi persyaratan kebersihan untuk pencegahan dan kontrol Covid-19.

5. Wajib bagi siapa pun yang berusia enam tahun ke atas untuk mengenakan masker saat berada di depan umum, baik di dalam maupun di luar ruangan.

6. Perlu alat pemisah antara pengemudi taksi dan penumpang.

7. Semua wisatawan dari negara-negara berisiko tinggi akan sangat dianjurkan untuk mengikuti tes Covid-19 setidaknya 72 jam sebelum berangkat ke Indonesia. Sementara itu, mereka yang dari negara berisiko rendah dapat diuji seminggu sebelum mengunjungi Indonesia. Pengunjung juga perlu melengkapi online Embarcation/Disembarcation Card (ED card) yang menanyakan serangkaian pertanyaan kesehatan yang terkait dengan gejala Covid-19.

8. Memberi wisatawan pilihan untuk memberikan hasil tes negatif yang diambil tidak lebih dari 72 jam sebelum kunjungan, atau menerima tes pada saat kedatangan. Biaya tes harus dibayar dimuka ditanggung oleh wisatawan.

9. Perlu memperkenalkan perlindungan wajib asuransi.

10. Wisatawan manca negara yang tidak memberikan hasil tes negatif dari laboratorium yang terakreditasi atau diakui, pada saat kedatangan akan dikarantina dengan biaya mereka sendiri sampai hasilnya diterima. Ini mungkin memakan waktu hingga 48 jam.

11. Wisatawan yang akan datang ke Indonesia perlu memberikan sertifikat valid yang membuktikan bahwa mereka telah menguji Covid-19 dengan hasil negatif, dan mereka akan dikenakan pemeriksaan suhu pada saat kedatangan serta pengujian secara acak selama perjalanan mereka. 
12. Perlu disusun anti-crisis plan yang mencakup kampanye pemasaran yang dirancang untuk mempromosikan Indonesia sebagai tujuan yang aman.

13. Sebagai bagian dari langkah-langkah untuk menahan penyebaran Covid-19, wisatawan dan pebisnis internasional diwajibkan untuk mengisi formulir penumpang yang terperinci. The Passenger Locator Form (PLF) harus diisi secara online setidaknya 48 jam sebelum memasuki negara dan mencakup informasi seperti durasi masa inap sebelumnya di negara lain selama dua minggu sebelum perjalanan, dan alamat tinggal di Indonesia.

14. Indonesia's Civil Aviation Authority (ICAA) atau Otoritas Penerbangan Sipil Indonesia perlu menyiapkan kode QR berdasarkan algoritma yang akan menghitung wisatawan yang paling berisiko menyebarkan infeksi virus corona. Pihak berwenang akan menggunakan kode QR untuk mengidentifikasi penumpang yang perlu diuji pada saat kedatangan. Mereka yang diuji harus dikarantina semalam menunggu hasil. Mereka yang dinyatakan positif akan dikarantina hingga 14 hari.

15. Para wisatawan memiliki opsi untuk mengajukan tes Covid-19 pada saat kedatangan, memberikan bukti tes yang baru diambil dengan hasil negatif, atau menyetujui karantina dua minggu.

16. Pengunjung juga didorong mengunduh aplikasi Rakning C-19, yang dirancang untuk membantu melacak asal-usul transmisi dan tersedia dalam berbagai bahasa. Hal ini dilakukan di Iceland disebut dengan The app Rakning C-19 .

17. Para wisatawan yang berkunjung ke Indonesia diminta untuk mengisi formulir otorisasi perjalanan dalam waktu 72 jam sebelum keberangkatan dan bersedia menjalani tes untuk Covid19 pada saat kedatangan.

18. Indonesia negara besar terdiri dari beribu-ribu pulau kecil, perlu menawarkan paket jangka panjang destinasi di pulau-pulau kecil dimana pemantauan kesehatan dapat dengan mudah dikendalikan.

19. Wisatawan tidak diharuskan untuk menjalani tes Covid-19 sebelum perjalanan, semua pengunjung akan menerima evaluasi medis, termasuk pemeriksaan suhu, pada saat kedatangan. Jika ada kecurigaan, wisatawan akan dibawa untuk tes PCR. Pengukuran akan dimulai di bandara.

20. Pemerintah perlu menetapkan pedoman baru untuk fasilitas hotel dan resor, seperti pemeriksaan suhu di pintu masuk dan setidaknya 12 jam ventilasi kamar dibuka setelah checkout. Para tamu akan diminta untuk memakai masker wajah dan menjaga jarak sosial. Tamu hotel dapat check-in ke kamar 24 jam setelah tamu sebelumnya check-out.

21. Membuka pusat pengujian coronavirus drive-through, tes tanpa biaya.

22. Indonesia perlu memperbesar kapasitas tes PCR/Swab (bukan rapid test)

23. Demi keamanan bersama dan mengendalikan penyebaran pandemi Covid-19, wisatawan yang akan datang ke Indonesia diminta untuk mengisolasi diri untuk periode 14 hari. Semua kedatangan harus memberikan alamat, di mana mereka harus menetap selama dua minggu. Mereka yang melanggar aturan akan dikenakan denda dalam bentuk uang dengan besaran tertentu. Keputusan ditinjau setiap tiga minggu. 
24. Mengadakan training untuk menambah jumlah contact tracer

25. Meningkatkan tes Covid-19 membutuhkan anggaran yang besar. Untuk itu, perlu menyisir kembali perencanaan dan penganggaran K/L/D yang selama ini dikritisi oleh para ahli belum mencerminkan kepekaan terhadap krisis pandemi Covid-19.

Ketika para wisatawan ke Indonesia, Indonesia harus memilik mekanisme untuk melindungi para wisatawan dan mengendalikan pandemi dengan baik. Strategi Indonesia dalam pengujian, pelacakan, dan isolasi berskala besar perlu pembuktian.

Belajar dari kegagalan negara-negara lain dalam mengendalikan pandemi Covid-19, salah satu faktor penyebabnya adalah para pengambil keputusan kurang mendengar pandangan-pandangan para ahli atau dengan kata lain keputusan-keputusan pengendalian Covid-19 kurang berbasis ilmu pengetahuan. Harapannya para pengambil keputusan di Indonesia di luar dari negara tersebut.

\section{Daftar Pustaka}

Carrier JG and Macleod DVL. (2005) Bursting the Bubble: The Socio-cultural Context of Ecotourism. The Journal of the Royal Anthropological Institute 11: 315-334.

Cohen E. (1972) Toward a Sociology of International Tourism. Social Research 39: 164-182.

Enzensberger HM. (1958) Vergebliche Brandung der Ferne. Merkur 12: 701720. https://www.bbc.com/indonesia/indone sia-53269897

https://www.theaustralian.com.au/breakingnews/transtasman-bubble-shelved-aftervic-spike-but-airports-are-ready-togo/newsstory/578200f7412393041a60a 9e47e91c1c4

https://www.stuff.co.nz/travel/news/121905 826/why-the-transtasman-travelbubble-is-dead

https://www.aljazeera.com/news/2020/05/ba ltics-launch-europe-pandemic-travelbubble-2005 14222830238.html

https://blog.wego.com/whats-a-travelbubble/

https://www.news.com.au/travel/travelupdates/transtasman-bubble-shelvedafter-vic-spike-but-airports-are-readyto-go/newsstory/578200f7412393041a60a9e47e91c $1 \mathrm{c} 4$

https:// timesofindia.indiatimes.com/travel/de stinations/australia-and-new-zealandjoin-hands-to-introduce-a-travel-bubblebetween-the-borders/as75575425.cms

https://www.destinasian.com/blog/newsbriefs/japan-to-begin-talks-with-10countries-on-easing-travel-bans

Jacobsen JKS. (2003) The Tourist Bubble and the Eurpeanisation of Holiday Travel. Tourism and Cultural Change 1: 71-87. 